\title{
Impact of Socio-Economic Status on Prevalence of Overweight and Obesity among Children and Adolescents of Amravati District (M.S.)
}

\author{
S. S. Nimgare, ${ }^{1}$ U. W. Fule, ${ }^{2}$ A. S. Patankar ${ }^{3}$ P. M. Telkhade ${ }^{4}$ \\ 1 \& 2- Department of Zoology, Hutatma Rashtriya Arts and Science College, \\ Ashti, Dist: Wardha, 3 \& 4- Arts \& Science College, Tukum,Dist.Chandrapur \\ Mahatma Gandhi Ayurved Mahavidyalaya Salod, Dist: Wardha \\ E-mail: patankar.kargi@gmail.com
}

\begin{abstract}
:
The present investigation was carried out to study the impact of socio-economic status on the prevalence of overweight and obesity among the children and adolescents of Amravati District. In the present comparative study, body weight and body mass index (BMI) values were significantly higher in the children studying in Private Public schools as compared to children studying in Government -aided schools. Similar results were observed in the children of all age groups. Out of 120 students of age group 2-6 yrs. studying in Government-aided school, 41 were under weight, 72 were of normal weight, 7 were overweight and nobody showed class-I, class- II and class- III type of obesity while in the same age group, out of 120 children studying in Private Public School, only 9 were under weight, 52 were having normal weight, 37 were overweight and 12 showed class- I type of obesity and 10 showed class II type of obesity and nobody showed class III type of obesity.

In the age group 6-12 yrs., out of 120students studying in Govt. aided School, 42 were under weight, 70 were of normal weight, 8were overweight and nobody was obese while in the same age group out of 120students studying in Private Public Schools, 6were under weight,50 were of normal weight, 40 were overweight ,13showed class-I and 11 showed class-II obesity. In the age group 1216 yrs., out of 120 students studying in Govt. aided School, 40were underweight, 74 were of normal weight, 6 were overweight and nobody showed any type of obesity while in the same age group, out of 120 students studying in Private Public Schools, 8 were under weight, 42 were of normal weight, 45 were overweight, 15 showed class- I and 10showed class- II type of obesity. Predominance of overweight and obesity in children having high socio-economic status and studying in Private Public Schools was due to their luxurious life style, fast food eating habits and loss of physical exercise. In adolescent females overweight was observed on the onset of puberty.
\end{abstract}

\section{Keywords:}

Children, obesity, Socio-economic status, Prevalence, Amravati District.

\section{Introduction:}

Obesity is a medical condition in which excess body fat has accumulated to the extent that it may have an adverse effect on health, leading to reduced life expectancy and/or increased health problems (Elias et al., 2005; Chu et al., 1998). Childhood obesity is a major emerging public 
health issue in developing countries, whereas it has reached epidemic proportions in industrialized nations. In Indian children overweight and obesity are common among middle and high income groups; however in the developed nations a higher prevalence of childhood obesity can be seen in the low socio economy group (Goyal et al., 2010; WHO report, 2003). Childhood obesity affects both developed and developing countries of all socio economic groups irrespective of age, sex or ethnicity. It has been estimated that worldwide over 22 million children under the age of 5 are obese, and one in 10 children is over weight in developing countries. Children of the upper socio economy strata are more likely than poor children to be obese. Indian data regarding current trends in childhood obesity are emerging. A recent steady conducted among 24000 school children in south India showed that the proportion of overweight children increased from $4.94 \%$ of the total students in 2003 to $6.57 \%$ in 2005 demonstrating the time trend of this rapidly growing epidemic.

A study from India reported that awareness levels about childhood obesity among school children are generally poor (Shabana and Vijay, 2010). Increasing trends in obesity seen among urban Indian children combined with the poor awareness levels have led to initiation of many interventional strategies throughout the country. The present study was carried out to study the impact of socio-economic status on prevalence of overweight and obesity among children and adolescents of Amravati District.

\section{Material and methods:}

The prospective study was undertaken on the children studying in Government aided schools and Private Public schools from April 2011 to June 2011 to study the impact of socioeconomic status on prevalence of overweight and obesity among children and adolescents of Amravati District. For the present study total six schools were selected from Amravati District of which three were Govt. aided and remaining three were Private Public schools. Total students under the research were 720 out of it, 360 were from Govt. aided schools and remaining 360 from Private Public schools. Total 360 students from each type of schools were divided in to three age groups 
as 2-6 years, 6-12 years and 12-16 years. From each age group 120 students were examined. In each age group equal number of males and females were selected. Consent was obtained from parent or guardians of all children who were offered the study as well as head masters of the respected schools.

Body Mass Index (BMI) of all children in the study groups was calculated as weight $(\mathrm{Kg}) /$ height square $\left(\mathrm{m}^{2}\right)$. The degree of obesity was calculated using international cut off points for body mass index for overweight and obesity by sex between 2 and 18 years according to Cole's reference data (Cole, et al., 1990) and (WHO, 1998) criteria . Depending on BMI school children were classified as follows :

$<18.5$ (Underweight), 18.5 - 24.9 (Normal weight), 25.0 - 29.9 (Overweight), 30.0 -34.9 (Class I obesity), 35.0 - 39.9 (Class II Obesity) and $\geq 40.0$ - (Class III obesity).

BMI was calculated by dividing the subject's mass by the square of his or her height, typically expressed either in metric or US customary units. Metric: $\mathrm{BMI}=\mathrm{Kg} \cdot / \mathrm{m}^{2}$

\section{Results:}

In the present comparative study, body weight and body mass index (BMI) values were significantly higher in the children studying in Private Public schools as compared to children studying in Government -aided schools. Similar results were observed in the children of all age groups. Out of 120 students of age group 2-6 yrs. studying in Government-aided school, 41 were under weight, 72 were of normal weight, 7 were overweight and nobody showed class-I, class- II and class- III type of obesity( Table 1) while in the same age group, out of 120 children studying in Private Public School, only 9 were under weight, 52 were having normal weight, 37 were overweight and 12showed class- I type of obesity and 10 showed class II type of obesity and nobody showed class III type of obesity (Table 2).

In the age group 6-12 yrs., out of 120students studying in Govt. aided School, 42 were under weight, 70 were of normal weight, 8 were overweight and nobody was obese (Table 1) while in the same age group out of 
120students studying in Private Public Schools, 6 were under weight,50 were of normal weight, 40 were overweight ,13 showed class-I and 11 female showed class-II obesity( Table 2).

In the age group 12-16 yrs., out of 120 students studying in Govt. aided School, 40 were under weight, 74 were of normal weight, 6 were overweight and nobody showed any type of obesity (Table 1) while in the same age group, out of 120 students studying in Private Public Schools, 8 were under weight, 42 were of normal weight, 45 were overweight, 15 showed class-I and 10 showed class-II type of obesity (Table 2). Predominance of overweight and obesity in children having high socioeconomic status and studying in Private Public Schools was due to their luxurious life style, fast food eating habits and loss of physical exercise. In adolescent females overweight was observed on the onset of puberty.

\section{Result and discussion:}

An important finding of this study is an ever burgeoning prevalence of overweight among the children studying in private schools as compared to the children studying in Govt. aided Schools because generally poor children having lower socio-economic status study in Government aided Schools as they cannot afford high fees of Private Schools while children of upper socioeconomic status study in Private Public Schools. Body mass index values and obesity in school children were compared to previous surveys in India (Sharma et. al., 2007). (Subramanyam et al., 1998) showed the prevalence of overweight and obesity among affluent girls aged 10-15 yrs. in Chennai was $9.6 \%$ and $6.2 \%$ respectively. Our study has shown higher figures which is suggestive of the obesity epidemic in $21^{\text {st }}$ century. Another finding of this study is the socio-economic influence in the prevalence of overweight and obesity. Prevalence of overweight and obesity was significantly higher among the children of upper socio- economic status. These results show consistency with results from other Indian studies (Marwah, et al., 2006).Female gender had higher preponderance to overweight and was more prominent in high society. However puberty and growth spurt which occur at an earlier age for girls may account to confounding effect. It has been 
reported that the number of adipose tissue cells increase during these periods followed by slow down after puberty (Hiersch, 1995).Results from different parts of the India and world also showed that female gender are at risk of being overweight and obese (Anthony et. al., 2000; Mohammad pour et al., 2003; Sidhu et al., 2006). Similar results that is, overweight in girls as compare to boys in adolescents were observed in the present study.

The study showed widespread prevalence of unhealthy lifestyle habits particularly in the children of upper socio-economic status who study in Private schools. It may be due to the fast food outlets and easy availability of junk food in the out yard of school. Today's children prefer these foods to fruits and vegetables (Gills and Bar, 2003; Merchant et al., 2007; Amin et al., 2008).

In present study, we found that the children from Private schools consumed more of fast food items and carbonated drinks as all these food items were easily available in their school canteen. Though the children were well informed about the good effects of physical activity, we found that they were not engaged in daily physical activity. Recent trend is that the school children concentrate more on academics and are involved in less of sports and activities. Leisure hours of children in upper socio-economic status are spent in watching TV or playing computer video games, thus explaining sedentary life style of today's school children. These findings were consistent with other studies (Anthony, et al., 2000; Merchant et al., 2007; Francisco et al., 2007; Pateric, 2004). Nevertheless obesity is the complex interaction between genetic and environmental factors (Sidney et al., 2004; Nobel et al., 2008).

\section{Conclusion:}

To summarize our results suggest that childhood obesity is on the rise especially among the high society children and the knowledge about lifestyle related diseases like obesity and diabetes and their prevention is very poor. Moreover the persistence of unhealthy practices among the most children be given attention. The health impact of increasing prevalence of overweight and obesity among children and adolescents is a matter of serious concern. 
Heart disease and diabetes were rare among children and young adults in the previous century. But today, supposed to be the diseases of the elderly ,these diseases are frequently occurring in the younger generation. This study has thus highlighted the need to not only improve the awareness of childhood obesity among children but a need to motivate and reinforce them to practice healthy life style is utmost essential.

\section{Acknowledgement:}

Authors are are thankful to honourable principal Hutatma Rashtriya Arts and Science College, Ashti, Dist. Wardha for his motivation and help during the present work. Thankfulness is also due to hon'ble principal Mahatma Gandhi Aurved Mahavidyalaya, Salod, for his untiring help during the colletion and data and past literature.

Table 1: Age, Gender and BMI specific classification of children studying in Government aided schools.

\begin{tabular}{|c|c|c|c|c|c|c|c|c|c|c|c|c|c|c|c|}
\hline \multirow{3}{*}{$\begin{array}{l}\mathrm{Sr} \\
\dot{\mathrm{N}} \\
\mathrm{o} .\end{array}$} & \multirow{3}{*}{$\begin{array}{l}\text { Age } \\
\text { group }\end{array}$} & \multirow{2}{*}{\multicolumn{2}{|c|}{$\begin{array}{l}\text { Total } \\
\text { children } \\
\text { examine } \\
\text { d }\end{array}$}} & \multicolumn{12}{|c|}{ Classification of children } \\
\hline & & & & \multicolumn{2}{|c|}{$\begin{array}{l}\text { No.of } \\
\text { Under } \\
\text { wt. (BMI } \\
<18.5 \text { ) }\end{array}$} & \multicolumn{2}{|c|}{$\begin{array}{l}\text { No. of } \\
\text { Normal } \\
\text { wt. (BMI } \\
18.5-24.9 \text { ) }\end{array}$} & \multicolumn{2}{|c|}{$\begin{array}{l}\text { No. of } \\
\text { Over wt. } \\
\text { (BMI } \\
25.0- \\
29.9 \text { ) }\end{array}$} & \multicolumn{2}{|c|}{$\begin{array}{l}\text { No. of } \\
\text { Class-I } \\
\text { obesity } \\
(30.0- \\
34.9)\end{array}$} & \multicolumn{2}{|c|}{ 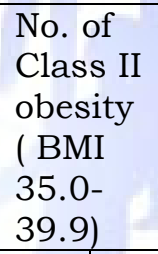 } & \multicolumn{2}{|c|}{$\begin{array}{l}\text { No. of } \\
\text { Class II } \\
\text { Obesity } \\
\text { (EMI } \\
>40)\end{array}$} \\
\hline & & $\mathrm{M}$ & $\mathrm{F}$ & $\mathrm{M}$ & $\mathrm{F}$ & $\mathrm{M}$ & $\mathrm{F}$ & $\mathrm{M}$ & $\mathrm{F}$ & $\mathrm{M}$ & $\mathrm{F}$ & $\mathrm{N}$ & $\mathrm{F}$ & M & $\mathrm{F}$ \\
\hline 1 & $\begin{array}{l}2-6 \\
\text { yrs. }\end{array}$ & 60 & 60 & 20 & 21 & 37 & 35 & 03 & 04 & $\mathrm{OC}$ & 0 & 0 & 00 & 00 & 00 \\
\hline 2 & $\begin{array}{l}6-12 \\
\text { yrs. }\end{array}$ & 60 & 60 & 21 & 21 & 35 & 35 & 03 & 05 & 0 & 00 & 0 & 00 & 00 & 00 \\
\hline 3 & $\begin{array}{l}12-16 \\
\text { yrs. }\end{array}$ & 60 & 60 & 21 & 19 & 37 & 37 & 02 & 04 & 0 & 00 & 0 & 00 & 00 & 00 \\
\hline
\end{tabular}

Table 2: Age, Gender and BMI specific classification of children studying in Private public schools.

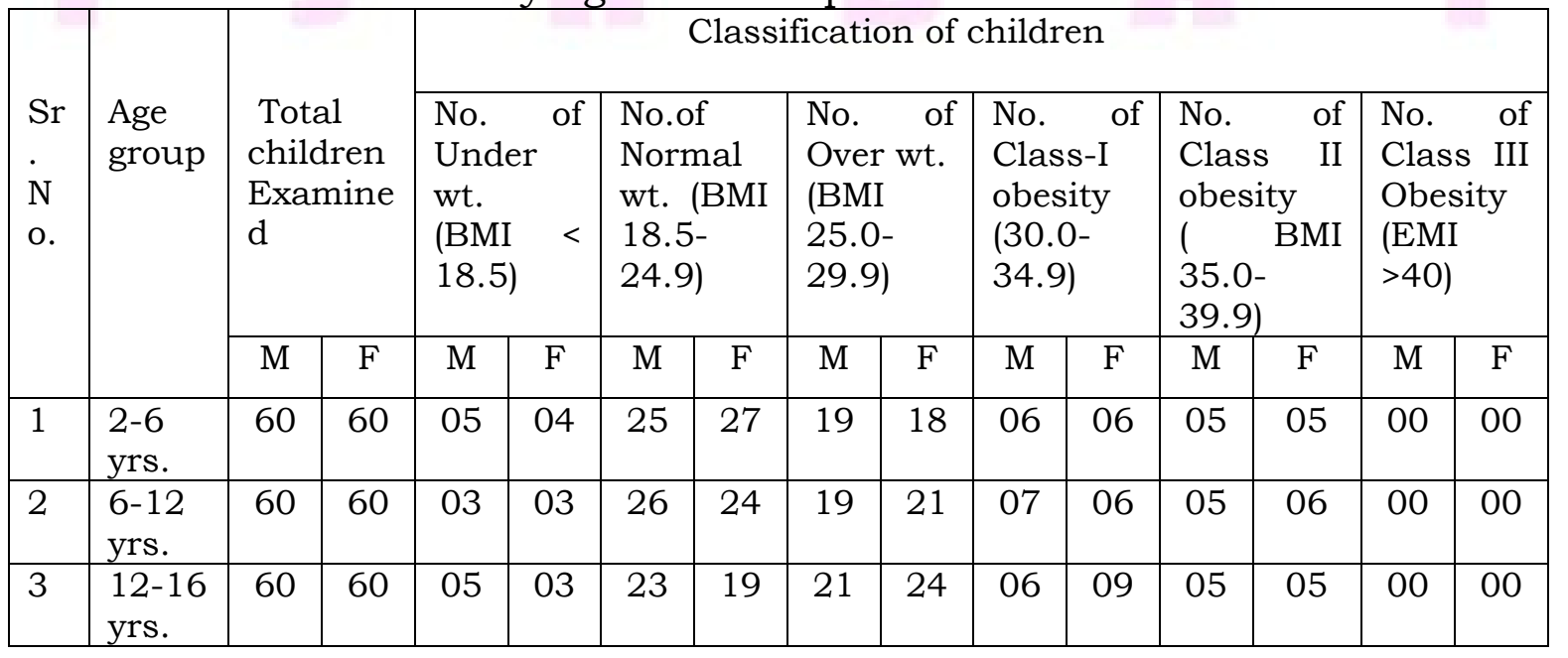




\section{References:}

Amin, T. T., Al-Sultan, A. I.,Ali, A. (2008) Overweight and obesity and their association with dietary habits, and socio-demographic among male primary school children in Al Hassa kingdom of Saudi Arabia. Ind. J. of Comp. Medi., 33(3) :172-181.

Anthony, J. G., Stewart, B. H.,Joel, G. (2000)Overweight among children and adolescents in a native Canadian community: prevalence and associated factors .Am. J. Clin. Nutri.71 :693-700.

Chu,N.F., Rimm,E.B., Wang,D.J., Liou,H.S. and Shieh, S.M.(1998) Clustering of cardio vascular disease risk factors among obese school children. The Taipei children Heart study .Am.J.Clin.Nutr. 67 : 1141-1146.

Cole, T.J., Bellini, M.C., Flegal, K.M. and Dietz, W.H.(2000). Establishing a Standard definition for child overweight and obesity worldwide : international survey, BMJ : 320:1240-1243.

Cole,T.J., Freeman, J.V., Preece, M.A.(1990). Body mass index reference curves for U.K. Arch. Dic child, 73 : 25-39 ( body mass index (BMI) or weight/height has been popular for assessing obesity in adults for many years but its use in children has developed only recenty.

Csab,G.,Torok, K.,Jeges, S.and Molnar, D.(2000). Presence of metabolic Cardio-vascular syndrome in obese children. Eur. J. Pediatr., 159: 91-94.

Elis L. J., Campbell K., Lidstone J., Kelly S., Lang R. and Summerbell C., (2005) prevention of childhood obesity best pract. Res. clin. Endocrinol. metab. 19: 441-454.

Francisco B. O., Jonaton R. R. and Michael S., (2007) Physical activity, overweight and central Adiposity in Swedish children and adolescents: the Europian youth heart study. Int. J. Behav. Nutr. Phys. Act. ,4: 61.

Gills L. J., Bar O. O., (2003) Food away from home, sugar-sweetened drink consumption and juvenile obesity. Am. Coll. Nutr.,22:539-545

Goyal R. K., Shah V. N., Saboo B. D., (2010) Prevalence of overweight and obesity in Indian adolescent school going children; its relationship with socio economic status and associated lifestyle factors. J. Assoc. Physicians India, 58,151-158.

Hirsch J., (1995) Fat cell number and size as a determinant of subsequent obesity: Childhood obesity, New York: John Willey and Sons.

Marwah R. K., Tandon N., Singh Y., (2006) A study of growth parameters and prevalence of overweight and obesity in school children from Delhi. Indian Pediatr. 43 (11):943-952. 
Merchant A. T., Dehghan M., Cook D. B. and Anand S. S., (2007) Diet, physical activity and adiposity in children in poor and rich neighbourhoods: A cross sectional comparison .Nutr. J. http://www.nutritionj.com/content/ $6 / 1 / 1$

Mohammadpour A. B., Rashidi A., Karandish M., Eshranghian M. R. and Kalantri N., (2003) Prevalence of overweight and obesity in adolescent Tehrani students, 2000-2001:an epidemic health problem. Public Health Nutr.; 7(5): 645-6

Nobel E. P., Blum K.,Ritchie T., Montgomery A. and Sheridan P. J., (2008) Allelic association of the D2 Dopamine receptor gene and obesity.Int. J. Eat. Disord., 15:20

Pateric K., Calfas G. J., Zabinski M. F., Cella J., (2004) Diet, Physical activity and secondary behaviors as risk factors for overweight in adolescence. Arch. Pediatr. Adolesc., 158:385-390.

Shabana T. and Vijay V., (2010) Chennai slim and fit programme. Awareness and perceptions related to obesity among urban children and adolescents. J. Assoc. physicians India (Tamilnadu state chapter), 2,29-23

Sharma A., Sharma K., Mathur K. P., (2007) Pattern and prevalence of obesity in affluent school children of Delhi Public Health Nutri.,10(5): 485489.

Sidhu S., Kaur N. and Kaur R., (2006) Overweight and obesity in affluent school children of Punjab. Ann. Hum. Biol;33(2):255-259.

Subramanyam V., Jayashree R. and Rafi M., (2003) Prevalence of overweight and obesity in affluent adolescent girls in Chennai in 1981 and 1998. Indian Pedriatr.,40:332- 336.

Sydney E. E., Walts B., Perusse L., (2004)The human obesity gene map :the 2003 update ,Obes. Res.;12:369-439. Update on the 1987 Task force Report on the High Blood pressure in Children and adolescents : a working group report from the National High Blood Pressure Education Programme working group on Hypertension control in children and adolescent Pediatrics (1996); 98(4pt.1) : 649-658. 